\title{
ODNALEŹĆ PHRONESIS W AISTHESIS. PAUL RICOEUR WOBEC SAMOTNOŚCI WYBORU I DZIAŁANIA
}

Ziemia człowieka jest planeta niedoświadczenia...

Milan Kundera

Jeśliby zgodzić się z użytą jako motto niniejszego tekstu sentencją jednego z największych filozofów wśród pisarzy, tedy przyznać trzeba, że podstawowym kondycyjnym rysem człowieka, mieszkańca Ziemi, jest niepokój. Niepokój jest przeciwieństwem arogancji, egzystencjalnym światoodczuciem wynikającym ze świadomości nieprzezwyciężalnej niewiedzy, podczas gdy arogancja jest życiową postawą opartą na przekonaniu o znajomości tego, co słuszne².

Paradygmatyczną sytuacją etycznego niepokoju, niepokoju wynikającego z odpowiedzialnego wyboru, jest scena otwierająca Nieznośna lekkość bytu Milana Kundery (to w autokomentarzu do tej powieści padły słowa „planeta

${ }^{1}$ M. Kundera, Sztuka powieści, tłum. M. Bieńczyk, Warszawa 2004, s. 121.

2 Postawa arogancji niejako z definicji opiera się na posiadaniu i respektowaniu tego, co Leszek Kołakowski określił jako kodeks: „Wierność, posłuszeństwo i honor - oto ulubione cnoty konserwatysty, cnoty czysto formalne i dające się scharakteryzować tylko przez trwałość pewnego związku, jaki łączy osobnika z inną rzeczywistością ludzką czy nadprzyrodzoną. Konserwatyzm ceni przewidywalność przyszłości [...], pozwala uchylić się od odpowiedzialności przez tworzenie sobie trwałych i bezwzględnych hierarchii wartości, to znaczy przez tworzenie kodeksów etycznych"; L. Kołakowski, Etyka bez kodeksu, [w:] tegoż, Kultura i fetysze. Eseje, Warszawa 2000, s. 148-149. 
niedoświadczenia"), w której główny bohater, Tomasz, stojąc nad ranem przy oknie swego mieszkania, zastanawia się, czy ma zaproponować Teresie, poznanej niedawno kelnerce, z którą spędził kilka nocy i do której poczuł zaskakującą dla siebie „niezmierną miłość”, by została w Pradze i z nim zamieszkała, czy nie? Czy to, co do niej czuje, to miłość prawdziwa, taka, której warto zawierzyć i poświęcić jej wszystko, czy tylko manipulacje libido, "tchórzliwej podświadomości”, , "histeria człowieka, który w głębi duszy uświadamia sobie swą niezdolność do kochania i zaczyna wmawiać sobie miłość" 3 ? Tomasz chce dobra, tak swojego, jak i Teresy, jednak nie potrafi zdecydować się na żadną z opcji, bowiem nie zna (dalekosiężnych) konsekwencji swojego wyboru. Jest, jak każdy, kto dokonuje wyboru, zawieszony in medias res, w niepokojącym "teraz", w którym "powinien natychmiast działać”, a nie może, a przynajmniej nie potrafi, uczynić tego „w zgodzie ze sobą".

W wykładzie Egzystencjalizm jest humanizmem Jean-Paul Sartre podaje analogiczny wobec „kazusu Tomasza” przykład swojego ucznia, który przeszedł do niego po radę. Uczeń ów zastanawiał się, czy powinien przyłączyć się do ruchu oporu - mowa tu o czasach II wojny światowej - i w trosce o swą ojczyznę walczyć z nazistami, czy raczej pozostać ze swoją samotną i schorowaną matką, jest bowiem jedynym jej dzieckiem. Sartre nie udzielił mu żadnej porady, a jedynie zasugerował, że wybierając jako doradcę swego nauczyciela (i znając jego poglądy), uczeń ów już sam zdecydował, co ma czynić, i właściwie nie porady, a potwierdzenia swojej decyzji poszukiwał. Poprzez ów akt „złej wiary” uczeń ów próbował niejako zanegować swoją (ludzką) egzystencjalną kondycję osamotnienia (la delaissement), czy raczej starał się z niej - poprzez poradę, wsparcie, dialog - wydobyć.

Sartre twierdzi, że nie sposób podjąć decyzji, a następnie usprawiedliwić jej konsekwencji, odwołując się do „natury ludzkiej”, wyższej instancji czy też autorytetu. Człowiek skazany jest „na wolny wybór bez usprawiedliwień i oparcia"4. "Nie mamy” - pisze filozof - "ani poza sobą, ani przed sobą, w dziedzinie wyższych wartości, potwierdzenia czy usprawiedliwienia. Jesteśmy sami, nikt nas nie usprawiedliwi [podkr. P.J.]"5.

Ktoś, kto nie podziela takiej egzystencjalistycznej, wynikającej częściowo z ateizmu i umiarkowanego nihilizmu6, perspektywy, mógłby odpowie-

\footnotetext{
${ }^{3}$ M. Kundera, Nieznośna lekkość bytu, tłum. A. Holland, Warszawa 2001, s. 4-5.

${ }^{4}$ J.-P. Sartre, Egzystencjalizm jest humanizmem, tłum. J. Krajewski, Warszawa 1998, s. 71.

${ }^{5}$ Ibidem, s. 37.

${ }^{6}$ Umiarkowany, gdyż nie chodzi tu o przekonanie, że wartości jako takie nie istnieja, co o zrelatywizowanie ich do konkretnych sytuacji, w których przychodzi im się sprawdzić. Stanowisko takie określa się w filozofii jako sytuacjonizm etyczny.
} 
dzieć, że to respektowana hierarchia wartości stanowić powinna niezawodny i osobisty drogowskaz przy podejmowaniu decyzji i działań7. Pojawiają się tu jednak trojakiego rodzaju zasadnicze problemy. Po pierwsze, stosunek między konkretnym wyborem a wartością, której zostaje on podporządkowany, jest nieuchronnie stosunkiem interpretacyjnym (samo rozumienie danej wartości jest również podporządkowane subiektywnej w znacznym stopniu wykładni). Po drugie, częstokroć dany wybór poprzedzony być musi wyborem między wartościami - zaprowadzeniem między nimi hierarchii, poświęceniem jednej wartości drugiej. Po trzecie wreszcie, z punktu widzenia osoby podejmującej działanie nie może być wówczas mowy o żadnej innej moralności niż tak zwana moralność intencji, niezbyt ceniona $\mathrm{w}$ wielu koncepcjach etycznych ${ }^{8}$.

Można uznać, że to właśnie wybory, wybory tragiczne, angażujące odpowiedzialność i związane $\mathrm{z}$ niepokojem, stanowią kluczowy element wszelkich narracji o życiu: narracji autobiograficznych, orientujących, tożsamościowych. Tym samym wybory owe stanowić powinny zasadniczy wątek w filozoficznych projektach narracyjnej teorii tożsamości, zwłaszcza że projekty te są jednocześnie (tak jest u trzech filozofów, którzy wyłożyli najpełniejszy program koncepcji tożsamości narracyjnej - Charlesa Taylora, Alasdaira MacIntyre'a i Paula Ricoeura) pewnymi propozycjami etyki.

Zasadniczy problem z narracyjnym ujęciem wyboru i działania polega na tym, że z konieczności jest ono czynione ex post, najczęściej niejako wbrew zaprowadzonej linearności - „od tyłu” ${ }^{2}$, z perspektywy znajomości

\footnotetext{
${ }^{7}$ Heinrich Rickert określił to jako „odniesienie do wartości” (Wertbziehung) pochodzących z "drugiego królestwa"; zob. H. Rickert, Człowiek i kultura, [w:] Antropologia kultury, red. Z. Mencwel, Warszawa 2001. Zob. też szkic prof. Władysława Stróżewskiego Człowiek $i$ wartości zamieszczony $\mathrm{w}$ niniejszym tomie.

${ }^{8}$ Przegląd stanowisk etycznych pod kątem stosunku do intencji przedstawia Jacek Hołówka w książce Etyka w działaniu, Warszawa 2002, s. 11. W Ewangelii świętego Marka Jezus co prawda wypowiada znamienne słowa „Poznacie ich po ich owocach” (Mt 7,16), ale skoro padają one w określonym kontekście - przestrogi przed zaufaniem fałszywych proroków - nie były odczytywane jako deklaracja przewagi konsekwencji nad intencjami. I tak etyka scholastyczna, na przykład w wydaniu Piotra Abelarda, odróżniała domenę podległą prawu Boskiemu (właśnie intencje) i prawu ziemskiemu (konsekwencje), utrzymując, że grzeszy się przede wszystkim myślą - złym, haniebnym zamiarem; złe konsekwencje szczytnych intencji nie stanowią zaś wykroczenia moralnego, ale podlegają jurysdykcji prawa; zob. Piotr Abelard, Etyka, czyli poznaj samego siebie, [w:] tegoż, Rozprawy, tłum. L. Joachimowicz, Warszawa 1969. Moralność intencji była szeroko krytykowana w utylitarystycznych koncepcjach etycznych.

9 "Wydarzenia dzieją się w jednym kierunku, a my opowiadamy je w kierunku przeciwnym. Pozornie zaczynamy od początku [...], a w rzeczywistości rozpoczęliśmy od końca. Ten koniec jest tutaj, niewidoczny, lecz obecny, to on nadaje splendoru i znaczenia początkowi"; J.-P. Sartre, Mdłości, tłum. J. Trznadel, Kraków 2005. s. 51.
} 
końca, choćby nieostatecznego, czyli już konsekwencji, nie zaś tragicznego "teraz" wyboru, które tym samym zostaje niejako zapoznane ${ }^{10}$.

Narracyjna optyka na własną egzystencję nie jest w stanie dostarczyć jednostce wsparcia czy instrukcji postępowania. Jeśli postulaty narracyjnie zorientowanych filozofów podmiotu i etyków da się sprowadzić do pewnego rodzaju imperatywu narracyjnego - postępuj tak, byś z punktu widzenia późniejszej opowieści przedstawiony został jako ten, który postapił dobrze, stusznie, właściwie - to nie przezwycięża on niepokoju odpowiedzialnego wyboru, a wręcz go sankcjonuje.

Taylor - jeśli moje odczytanie jego myśli jest słuszne - nie rozwiązuje tego problemu, a właściwie, należałoby rzec, nie przedstawia konkretnych dyrektyw rozrachunku i postępowania, a zamiast tego podaje jeden możliwy (własny?) przykład jego rozwiązania.

U kanadyjskiego filozofa narracyjność egzystencji ufundowana jest na metaforze sytuacji etycznej człowieka przedstawionej jako poszukujące poruszanie się wewnątrz „moralnej przestrzeni”. Przestrzeń tę wyznaczają: horyzont moralny (dobro najwyższe, czyli zrealizowanie ideału bycia „pełnym" człowiekiem) oraz ramy pojęciowe składające się $\mathrm{z}$,jakościowych rozróżnień, [czyli] jakiegoś wyobrażenia na temat tego, co nieporównanie wyższe"11. Realizowanie najwyższego/nadrzędnego dobra poprzedzone musi być jednak samonarzuceniem go sobie jako kryterium. Dopiero wówczas możliwe jest zaprowadzanie jakościowych rozróżnień, czyli hierarchii między dobrami pomniejszymi ${ }^{12}$. I w jednym, i w drugim przypadku od-

10 „Zawsze znajdą się powody a posteriori dla każdego działania, nawet kompletnie pozbawionego podstaw lub niegodziwego, zawsze można je znaleźć, czasem są śmieszne i niewiarygodne, bezzasadne, takie, które nie zwiodą nikogo albo tylko tego, kto je wymyśla. Ale powód zawsze się znajdzie. [...] W istocie łatwiej znaleźć takie powody dla czegoś, co już się zdarzyło, niż planów i intencji, dla propozycji, decyzji. To, co już się wydarzyło, jest bardzo mocnym, solidnym punktem wyjścia: jest nieodwracalne, dostarcza wzorca, wskazówki. Jest czymś, czego można się trzymać. A nawet czego można przestrzegać, ponieważ związuje i zobowiązuje [...]. Dużo łatwiej podać przyczyny na wytłumaczenie tego, co już było (albo je znaleźć lub - dlaczego nie? - dostarczyć, co sprowadza się do tego samego), niż usprawiedliwić zawczasu coś, co pragniesz, by się zdarzyło, co starasz się spowodować"; J. Marías, Twoja twarz jutro. Taniec $i$ sen, tłum. E. Zaleska, Katowice 2011, s. 51. Nieprzypadkowo cytaty polemiczne wobec teorii narracyjnej czerpię z literatury. To $\mathrm{z}$ niej bowiem wyszła najsilniejsza kontra wobec narracyjnych koncepcji tożsamości.

${ }^{11}$ Ch. Taylor, Źródta podmiotowości. Narodziny tożsamości nowoczesnej, przekład zbiorowy, oprac. T. Gadacz, wstęp A. Bielik-Robson, Warszawa 2001, s. 93.

12 „Nawet ci z nas, którzy nie są aż tak bardzo zdecydowani, uznają jakieś wyższe dobra. Uznajemy, innymi słowy, jakościowe rozróżnienia pierwszego rzędu, które definiują wyższe dobra, dzięki czemu dokonujemy rozróżnień pomiędzy pozostałymi dobrami, przypisujemy im różną wartość, ustalamy, kiedy i gdzie się do nich odwołać. Owe dobra najwyższego rzędu będę nazywał «dobrami nadrzędnymi», tzn. dobrami, które nie tylko są nieporównanie waż- 
powiedzialność spoczywa więc na osamotnionej jednostce, która zapętlona jest w zasygnalizowane powyżej problemy. Ponadto Taylor określa "przestrzeń moralną" jako nie tyle „przestrzeń sensów”, co „przestrzeń pytań”, „przestrzeń, w której człowiek szuka drogi”13.

Pierwsze dwieście stron tego ogromnego traktatu moralnego, jakim są Źródła podmiotowości, służy przede wszystkim przedstawieniu sytuacji etycznej człowieka, która bliska jest wyartykułowanemu przeze mnie powyżej obrazowi działającej jednostki jako nieuchronnie uwikłanej w związane z odpowiedzialnością wyboru niepokój i osamotnienie. Właściwie pozostałych siedemset stron Źródet podmiotowości (zakończonych, dodajmy, deklaracją, że jest to tylko wstęp do kolejnej książki i że problemy zostały jedynie postawione, nie zaś rozwiązane) można odczytać jako próbę wypracowania indywidualnej odpowiedzi na zasygnalizowane na początku wątpliwości i rozterki: artykulację czegoś, co mogłoby służyć za trwały horyzont dla opartych na narracjach wspólnotowych narracji indywidualnych. Dla Taylora będą to przede wszystkim dobra wola i oczyszczony z błędnych wartościowań ideał autentyczności ${ }^{14}$.

MacIntyre z kolei pisze, że działania i wybory jednostki stają się zrozumiałe dzięki „umiejscowieniu danego epizodu w kontekście narracji historycznych, narracji opisujących zarówno jednostki, których ów epizod dotyczy, jak i narracji dotyczących układów, w których one działają i odczuwają"15. W tym jednym określeniu - „stają się zrozumiałe” - zawiera się tak inteligibilność („rozumiem, dlaczego on to zrobił”), jak i alibizacja („to zrozumiałe, że to zrobił"). Zdanie "jestem w stanie to zrozumieć" znaczy jednocześnie "jestem w stanie to pojąć (rozumowo)" i ,jestem w stanie to usprawiedliwić", a przynajmniej - „nie potępiam tego". Podobnie zresztą funkcjonuje słowo „wyjaśnić”, zaś w przypadku czasownika „tłumaczyć” różnica ta jest zaznaczona poprzez jego dodatkowe funkcjonowanie $w$ trybie zwrotnym „tłumaczyć się". Już więc na płaszczyźnie języka w racjonalność wpisana zostaje pewna moralność ${ }^{16}$.

niejsze od innych, ale stanowią punkt odniesienia dla rozważań, decyzji i ocen dotyczących pozostałych dóbr"; ibidem, s. 126. Słowa „uznajemy” czy „ustalamy” wskazują wyraźnie na odpowiedzialność jednostki w tym procesie.

${ }^{13}$ Ibidem, s. 57.

14 Zob. też: Ch. Taylor, Etyka autentyczności, tłum. A Pawelec, Kraków 2002; w książce tej, będącej zapisem z cyklu wykładów Taylora, filozof powtarza i rozwija wiele wątków zainicjowanych w Źródłach podmiotowości.

15 A. MacIntyre, Dziedzictwo cnoty. Studium z teorii moralności, tłum. A. Chmielewski, Warszawa 1996, s. 378.

16 Pogląd ten wprost werbalizuje Charles Taylor: „«Oddawanie najlepiej sensu» oznacza, że [dane pojęcia - przyp. P.J.] nie tylko oferują najlepszą, najbardziej realistyczną orientację 
MacIntyre wsparcie dla osamotnienia podmiotu w jego wyborach odnajduje poprzez odniesienie do innych narracji i narracji Innych ${ }^{17}$. W tym pierwszym wypadku będzie to historia układów społecznych, które jednak nie tylko mają charakter wyraźnie ustalony i konserwatywny (a tym samym tłumią impulsy moralne $w$ jednostce, fałszywie zwalniając ją od odpowiedzialności), ale i wielokrotnie w historii okazywały się boleśnie nieskuteczne. Dodatkowo jednostka, nawet popierana i umacniana konkretnym układem społecznym, zawsze podejmuje decyzję samodzielnie, a więc - samotnie. Drugie wsparcie natomiast - narracji Innych: tych którzy dotknięci zostają moim działaniem, wplątani w moje wybory, albo chociażby są ich świadkami - niwelować ma możliwe zafałszowania - "manowce własnych iluzji”, jak to określa Zofia Mitosek ${ }^{18}$ - wynikające przede wszystkim z naturalnych skądinąd skłonności jednostki do usprawiedliwiania swych czynów. Jednak $\mathrm{i}$ to nie przekonuje, skoro inni są nie mniej niż ja zaplątani $\mathrm{w}$ "manowce własnych iluzji", jakże tedy mogą być należytymi, bezstronnymi arbitrami moich postępków?

Ponadto, MacIntyre zdaje się też nie dostrzegać zagrożenia płynącego ze strony perspektywizmu: co jeśli z perspektywy „jednego innego" moje zachowanie zostanie ocenione jako szczytne i chwalebne, "inny inny” uzna je zaś za haniebne? Czy jestem w stanie narracyjnie połączyć te dwie nieprzystajace perspektywy - a nawet dwie różne perspektywy, o mniejszej polaryzacji - bez uszczerbku dla „narracyjnej jedności życia”, czy muszę jednemu innemu przyznać rację, drugiemu zaś przypisać omyłkę lub kłamstwo? A jeśli to drugie, to na jakiej podstawie mam to uczynić, jeśli nie „manowców" - tym razem - własnych preferencji i interesów (dobrostanu psychicznego i moralnego, interesów „wizerunkowych”)? Czy zarówno przy odniesieniu do "historii układów”, jak i do "narracji Innych” nie jesteśmy nieuchronnie skazani na pewnego rodzaju mauvaise foi?

wobec dobra, ale również najpełniej umożliwiają pojmowanie i zrozumienie działań i uczuć naszych i innych ludzi. Albowiem nasz język namysłu moralnego płynnie przechodzi w język wartościowań, ten zaś w język, w którym wyjaśniamy to, co ludzie robią i czują" (Ch. Taylor, op. cit., s. 113). I dalej: „Pojęcia, których używamy do rozstrzygnięcia tego, co jest najlepsze, to w zasadzie te same pojęcia, których używamy do osądzania działań innych ludzi, te zaś z kolei w dużej mierze pojawiają się w naszych stwierdzeniach na temat tego, dlaczego ludzie postępują tak, a nie inaczej" (ibidem, s. 115). Nie sposób więc, jeśli chodzi o przedstawianie działania człowieka, oddzielić w języku poziomu opisowego od poziomu wartościującego.

17 „Każdy z nas, będąc głównym bohaterem własnego dramatu, odgrywa drugoplanowe role w dramatach innych ludzi"; A. MacIntyre, op. cit., s. 381.

18 Z. Mitosek, Dlaczego Paul Ricoeur nie napisat studium o autobiografii?, [w:] Horyzonty interpretacji. Wokót myśli Paula Ricoeura, red. A. Grzegorczyk, M. Loba, R. Koschany, Poznań 2003, s. 152. 
Poniżej postaram się odpowiedzieć na pytanie, jak z niepokojem i osamotnieniem odpowiedzialnego wyboru poradził sobie Paul Ricoeur w swojej teorii tożsamości narracyjnej. Podstawą będzie tu traktat $O$ sobie samym jako innym, a konkretnie: rozdziały siódmy i dziewiąty tej książki, których podtytuły - „Dążenie etyczne” i „Tragizm działania” - wprost zapowiadają odpowiedź na nurtującą mnie kwestię. I choć Ricoeur bardziej niż do zarysowanej powyżej na bohatera powieści Kundery i ucznia Sartre'a sytuacji odnosi się do (tragicznego) konfliktu między etycznym zobowiązaniem wobec drugiej osoby a obowiązkiem wynikającym $\mathrm{z}$ poszanowania prawa (przypadek Abrahama z „ofiarowania Izaaka"19 czy Antygony), to, jak sądzę, można z jego rozważań wyciągnąć wnioski zasadne i dla tego pierwszego problemu, a ponadto sedno niepokoju i osamotnienia - jak działać teraz? - pozostaje tożsame w obydwu wypadkach.

Paul Ricoeur, wychodząc od zgoła egzystencjalistycznych przesłanek i określając tożsamość jako słabą i bezbronną, wypracowuje w swej teorii tożsamości narracyjnej najmocniejszy fundament dla jej umocnienia $i$ obrony. W ramach kluczowego dla jego stylu filozofowania paradygmatu koncyliacji i „okrężnej drogi" (détour) sięga przy tym zarówno do Arystotelesowskiej kategorii „dobrego życia” (odniesienie do Arystotelesa w znacznym stopniu, co sam Ricoeur przyznaje, upodabnia jego koncepcję do poglądów MacIntyre'a), jak i do Kantowskiej normy jako spełnienia postulatu uniwersalizacji imperatywu kategorycznego. Kluczową strategią, na bazie której tożsamość narracyjna zostanie wzmocniona i obroniona, będzie u Ricoeura dialektyczne uzupełnienie oparte na produktywnym schemacie koła hermeneutycznego.

Dwie pierwsze pary, które Ricoeur wprowadzi w pozbawiony początku ruch wzajemnego uzupełniającego odnoszenia się do siebie, to moralność i etyka oraz poważanie siebie (éstime de soi-même) i szacunek dla siebie (respèct de soi-même). Tym, co powstanie jako efekt pracy hermeneutycznego koła, będzie natomiast szczególna "mądrość sądu sytuacyjnego", którą Ricoeur określi jako „przekonanie” (conviction) ${ }^{20}$.

${ }^{19}$ W tym temacie por. P. Ricoeur, Miłosne postuszeństwo, [w:] A. LaCocque, P. Ricoeur, Myśleć biblijnie, tłum. E. Mukoid, M. Tarnowska, Kraków 2003.

20 P. Ricoeur, O sobie samym jako innym, tłum. B. Chełstowski, wstęp M. Kowalska, Warszawa 2005, s. 409. Dalsze cytaty z tej pozycji lokalizuję bezpośrednio w tekście, podając numer strony. 
W niniejszym omówieniu interesować mnie będą indywidualne, egzystencjalne aspekty podmiotowości w myśli Ricoeura. Do dialogicznego (wyznaczonego przez Heideggerowską ideę troskliwości [Sorge, sollicitude]) jej wymiaru odniosę się jedynie $w$ tym aspekcie, $w$ jakim Inny jest jednostce niezbędny do konstytucji podmiotowej. Zdawkowo zaś i tylko wtedy, kiedy to będzie konieczne, nawiążę do aspektu politycznego (wyznaczonego przez ideę sprawiedliwości). Wszystkie te trzy wymiary wpisane są $\mathrm{w}$ definicję "dążenia etycznego" (visée éthique) jako podstawowego horyzontu podmiotowości: dążenie etyczne to „zamiar osiągnięcia «życia dobrego»" - wymiar egzystencjalny; „wraz z drugim człowiekiem i dla drugiego" - wymiar dialogiczny; "w sprawiedliwych instytucjach" - wymiar polityczny (s. 285).

By owo dążenie ugruntować, Ricoeur poszukiwać będzie „środkowej drogi" między miałkością "dobrej rady” a egzystencjalistycznym zaakceptowaniem tragicznej aporetyczności wyboru.

Etykę określa Ricoeur jako jednostkowe dążenie do spełnionego, pełnego, słowem - dobrego życia. Moralność jest zaś związaniem tego dążenia z normami nacechowanymi roszczeniem do powszechności, czyli jakby interpretacją prywatnych ideałów w języku wartości i postulatów, ich konkretyzacją (s. 282). Zgodnie z takim ujęciem, etyka nie tylko poprzedza moralność, ale i jest pojęciem szerszym, zawierającym ją w sobie.

Płaszczyźnie etycznej i moralnej przyporządkować można odpowiednio poważanie siebie i szacunek dla siebie. Poważanie jest stanem podstawowym, wyjściowym. Szacunek zaś zaistnieć może dopiero wtedy, gdy płaszczyzna etyczna związana jest z moralną. Szacunek jest więc poszanowaniem siebie pod panowaniem normy. W sytuacji, w której etyczność jednostki rozchodzi się z normą (którą to sytuację Ricoeur nazywa "aporią obowiąz$\left.\mathrm{ku}^{\prime}\right)$, „poważanie siebie okazuje się nie tylko źródłem, lecz ostoją szacunku, gdy żadna pewna norma nie służy już jako niezawodny przewodnik dla obdarzania siebie hic et nunc szacunkiem" (s. 283). Mówiąc inaczej - gdy jednostkowe dążenie do dobra nie odnajduje oparcia w prawno-społecznych instytucjach i praktykach, zaufać należy temu pierwszemu, zwłaszcza że nie tylko ryzyko solipsyzmu etycznego istnieje wyłącznie jako konsekwencja mylnego ontycznie postrzegania jednostki (zgodnego bowiem ze schematem introspekcji, nie zaś samo-uzewnętrznienia, właściwego oglądowi siebiejako-innego), ale i przez to dialogiczne odniesienie otrzymuje się przedwspólnotowy fundament, będący gwarantem dobra. U Ricoeura bowiem Inny, niezależnie od tego, czy aktualne rozważania zbliżają go do Arystotelesowskiego przyjaciela, nowotestamentowego bliźniego, Buberowskiego "Ty" czy Lévinasowskiej „twarzy”, zawsze jest związany z dobrem. Dobro 
Innego współgra z indywidualnym pragnieniem „dobrego życia”, umacnia je.

Arystoteles wyróżnił trzy rodzaje przyjaźni: opartą na korzyści, przyjemności i właśnie na dobru. Jedynie ta ostatnia jest prawdziwa, gdyż nie tylko przyjaciel nie jest w niej traktowany jako środek, lecz jako cel (tu znajduje Ricoeur punkt przejścia do Kantowskiego „państwa celów”, a zarazem możliwość przekroczenia jego abstrakcyjnej, pozapodmiotowej konstytu$\mathrm{cji}^{21}$ ), ale i wpisane $\mathrm{w}$ nią jest pragnienie zachowania przyjaciela takim, jakim jest, bo tylko jako-taki gwarantuje on wspól-dążenie do dobra ${ }^{22}$. Dodatkowo Arystoteles nazywa przyjaciela „innym ja” (héteros autós) i drugim ja (allos autós), co doskonale, na zasadzie dopełniającej symetrii, wpisuje się w kluczową dla tożsamości narracyjnej dialektykę soi-même comme un autre: $\mathrm{z}$ jednej strony , ja jako inny" Ricoeura, z drugiej - „Inny jako inny ja” Arystotelesa $^{23}$. Zauważyć można, że oba te sformułowania sytuują się równie daleko od niebezpiecznej depersonalizacji wpisanej $\mathrm{w}$ Rimbaudowskie Je est un autre.

$\mathrm{Z}$ innym jako, z jednej strony, do-pełnieniem tego-który-jest-sobą, z drugiej zaś - fundamentem wspólnotowości, związana jest u Ricoeura kluczowa w kwestii odpowiedzialnego wyboru kategoria atestacji (attestation). Atestacja - pisze Elżbieta Wolicka, komentatorka myśli autora Filozofii osoby:

jest testem szczerości, który motywuje zaufanie do tego, kto składa świadectwo swej osobowej wiarygodności - dotyczy ono zarówno czynu, jak i jego sprawcy. Akceptacja świadectwa równa się "poświadczeniu tożsamości” wystawionemu autorowi przez drugiego ${ }^{24}$.

21 Trzecie sformułowanie przez Kanta imperatywu kategorycznego, zwane także jako formuła państwa celów, wzywa do ustanowienia moralnej wspólnoty, w której wszystkie racjonalne istoty realizowałyby swoją wolność przez uznanie swojej własnej prawości i szczęścia innych jako celów samych w sobie. Zob. I. Kant, Uzasadnienie metafizyki moralności, tłum. M. Wartenberg, Warszawa 2002, s. 76-77. Państwo celów dopóty jest abstrakcyjnym państwem celów, nie zaś ludzi, dopóki nie uznamy, za Arystotelesem, że to człowiek jest celem. Stąd potrzeba hermeneutyczno-dialektycznej koncyliacji.

22 Zob. Arystoteles, Etyka Nikomachejska, tłum. D. Gromska, Warszawa 1956, księgi VIII-IX.

${ }^{23}$ "[Zdaniem Arystotelesa] bez przyjaciela nie da się nazwać życia «dobrym» ani «szczęśliwym» - Paul Ricoeur znajduje w tym potwierdzenie własnej tezy antropologicznej: samoakceptaja i szacunek dla siebie, a nawet samorozpoznanie własnej tożsamości okazują się niemożliwe bez dialogicznej wzajemności «ja» / «ty», na mocy której «bycie-sobą» jawi się równocześnie «jako-bycie-innym»"; E. Wolicka, Narracja i egzystencja. "Droga okrężna" Paula Ricoeura od hermeneutyki do ontoantropologii, Lublin 2010, s. 139.

${ }^{24}$ E. Wolicka, Odkrywanie tożsamości "Ja" - hermeneutyka Paula Ricoeura "w drodze” ku fenomenologii osoby, [w:] Horyzonty interpretacji, op. cit., s. 110. 
Oczywiście, sytuacja ta nie określa problematyki podejmowania decyzji, a tłumaczenie (się z) decyzji już podjętej. Jednakże a priori wyboru daje się wyrazić w kategoriach ex post dialogicznego poświadczenia: wybierz tak, by twój wybór i jego konsekwencje uzyskały w przyszłości akceptujaca atestacje inne$g o^{25}$. To zalecenie jednak, jak wskazałem już w przypadku tak MacIntyre'a, jak Tylora, uwikłane z jednej strony $\mathrm{w}$ „moralność intencji”, z drugiej zaś w asekuracje samointerpretacji (ujmującej wszystko jako, koniec końców, dobre, a więc czyniącej tak ze swej decyzji, jak z dobra, pole otwartej interpretacji). Nie znosi zatem ono podstawy niepokoju odpowiedzialnego wyboru.

Ricoeur czyta wnikliwie Etykę Nikomachejska, poszukując zasady możliwości przejścia między formułą rozsądku, „złotego środka” (phronesis) a człowiekiem rozsądnym (phronimos) wyposażonym w zdolność właściwego namysłu (boulesis), który mógłby wesprzeć Kantowską "dobrą wolę", czyli tę rzecz, którą „bez ograniczeń można by uznać za dobrą" ${ }^{26}$. Arystoteles pisze, że:

Rozsądek, czyli mądrość praktyczna, dotyczy spraw ludzkich i tych, nad którymi można się namyślać; mówimy bowiem, że rzeczą człowieka rozsądnego jest przede wszystkim dobry namysł, a nikt nie namyśla się nad tym, co nie może być inaczej lub nie ma żadnego celu; celem zaś jest dobro, które ma być osiągnięte przez działanie. Dobrze zaś w bezwzględnym tego słowa znaczeniu namyśla się ten, kto zgodnie z wynikami swego rozumowania umie zmierzać do największego dla człowieka dobra, które może być osiągnięte przez działanie ${ }^{27}$.

Między „dobrem osiągniętym przez działanie” a „największym dla człowieka dobrem osiągniętym przez działanie" rysuje się wychwycony przez Ricoeura paradoks phronesis: to pierwsze zdaje się możliwe dzięki wypracowanej w drodze „ćwiczenia w cnotach” predyspozycji człowieka, to

${ }^{25}$ Gdyby jednak dokonać ekstrapolacji struktury atestacji tak, by rozciągnąć ją na moment sprzed podjęcia działania, można by udzielić bardzo prostego antidotum na niepokój odpowiedzialnego wyboru: Tomasz nie powinien poszukiwać odpowiedzi poprzez samodzielne rozwiewanie własnych wątpliwości, lecz porozmawiać z Teresą, student nie powinien poszukiwać odpowiedzi poprzez niesamodzielne rozwiewanie własnych wątpliwości, a porozmawiać nie z Sartre' $m$, lecz ze swą matką. $W$ to rozwiązanie, zalecenie, niebezpiecznie zbliżające się do "dobrej rady” odrzuconej przez Ricoeura już na początku rozważań, wpisany jest jednak nieusuwalny błąd. $W$ takim bowiem stopniu, $w$ jakim dialogiczna struktura oznacza wspól-życie i współ-dążenie (do dobra w imię dobra), nie może abstrahować od siebie samej i zredukować się do poziomu przedmiotu decyzji/rozrachunku. W obu zaś przypadkach ta dialogiczna struktura, która miałaby być fundamentem decyzji, jest też jej przedmiotem: czy nadal współ-żyć z Teresą?, czy nadal współ-żyć z matką?

${ }^{26}$ I. Kant, op. cit., s. 11.

${ }^{27}$ Arystoteles, Etyka Nikomachejska, op. cit., ks. VI, § 8-17. 
drugie zaś wynika z pewnej przyrodzonej mu, intuicyjnej inklinacji (to, do czego dążysz, jest dobre, niemożliwym jest bowiem dążenie do czegoś, co jest złem). Upraszczając, to pierwsze wynikałoby z namysłu, to drugie zaś $\mathrm{z}$ natury.

Zwróćmy uwagę na z jednej strony relatywizującą, z drugiej - rozszerzającą wobec pierwszej formuły (w której występuje po prostu „dobro") frazę "największe dobro dla człowieka". Zakłada ona, po pierwsze, stopniowalność i hierarchię dóbr. Po drugie, sama będąc jednocześnie rozszerzeniem i relatywizacją, wprowadza swój przedmiot $\mathrm{w}$ stan analogicznej ambiwalencji. $\mathrm{Z}$ jednej strony, w przypadku takiego namysłu, którego przedmiotem będzie dobro dwóch lub więcej ludzi (w tym dobro samego podejmującego decyzję), nie pozwala odpowiedzieć na pytanie: dla człowieka, ale dla którego? Z drugiej jednak, gdy przedmiotem namysłu będzie dobro człowieka (kogokolwiek lub konkretnego kogokolwiek) i dobro nie-człowieka, nakazuje wybierać to pierwsze. Jeśli więc student Sartre'a wybierać musi między dobrem ojczyzny a dobrem swej matki - winien poświęcić się temu drugiemu. Rozwiązanie to jednak runie $w$ momencie, gdy uświadomimy sobie, że dla Arystotelesa pojęcie „człowiek" równoznaczne jest z pojęciem obywatela, a dobro człowieka uzależnione jest od sprawiedliwej struktury polis.

Niezależnie od tego, czy w kwestii dobra podążymy za filogenetyczną predyspozycją człowieka, czy za jego ontogenetyczną dyspozycją, „skazani jesteśmy” - jak pisze Wolicka - „na zmaganie się z notoryczną wieloznacznością pojęcia dobra jako celu dążenia oraz z nierozstrzygalną aporią zła i całkiem realną, jak uczy doświadczenie, możliwością złego wyboru" 28 . Arystoteles problem ten rozwiązać może kosztem zapoznania (a raczej: nierozpoznania) podwójnego źródła możliwości realizacji dobra. Zło jest dla niego wyłącznie konsekwencją niewłaściwego namysłu, niedostatecznego wyćwiczenia się $\mathrm{w}$ cnocie phronesis, pojęcie złej natury człowieka byłoby bowiem w jego optyce wewnętrznie sprzeczne. Jak to jednak możliwe, że człowiek na drodze rozumowo-praktycznego dopełniania swej natury może się jej sprzeniewierzyć - tego Stagiryta nie wyjaśnia. Zatrzymuje się na tezie mówiącej o podporządkowaniu trwałych dyspozycji - woli, przede wszystkim woli rozsądku.

W toku wnikliwej i krytycznej lektury Etyki Nikomachejskiej Ricoeur rozpoznaje kolejny paradoks myśli Arystotelesa: „Jak można [...] utrzymywać zarazem, że każda praktyka ma «cel w sobie samej» i że każde działanie zmierza ku «ostatecznemu celowi»?" (s. 145). W tym miejscu Ricoeur odchodzi od poglądów Arystotelesa, połączenia tych aspektów dokonuje zaś

${ }^{28}$ E. Wolicka, Narracja i egzystencja, op. cit., s. 139. 
poprzez odniesienie swojej teorii tożsamości narracyjnej do współ-myśli MacIntyre'a. Widać więc, że w takim stopniu, w jakim obaj oni bazują na Stagirycie, odejście to jest w rzeczywistości obejściem. Od autora Dziedzictwa cnoty przejmuje Ricoeur pojęcie immanentnych względem praktyk, a kulturowo sankcjonowanych „Wzorców doskonałości” (standards of excellence), sam zaś dokłada, jako transcendujące sferę praxis, pojęcie planu życia. Następnie zaś wydziela konkretne pola praktyk (życie zawodowe, rodzinne, polityczne, osobiste, społeczne), które zbliżają go do tego, co Ralph Linton określił jako „role społeczne" 29 . O ile jednak Linton zatrzymał się na synchronicznej bezkolizyjności ról jako podstawie spójnej osobowości ujmowanej hic et nunc, Ricoeur, wpisując wzorce doskonałości w teleologię "dobrego życia”, zmuszony jest wprowadzić zasadę pośredniczącą między polem praktyk (gdzie obowiązują „wzorce doskonałości”) i planem życia (gdzie obowiązuje wzorzec "dobrego życia”, wyznaczony przez cel "dążenia etycznego"). Zasadą tą, jak nietrudno się domyślić, będzie efektywna ekonomia koła hermeneutycznego, wsparta dodatkowo nie tylko Arystotelesowskim phronesis, ale i strukturą "interpretacji jako samointerpretacji” oraz prawem dialogicznej atestacji. Główna, anty-Hume'owska w swym duchu teza brzmi: $w$ teleologię wpisana jest deontologia. Ponownie więc aporia, w tym wypadku aporia bytu i powinności, okazuje się efektem błędnego rozpoznania ontycznego, które może znieść dialektyka koła hermeneutycznego:

Skoro zdoła się wykazać, że deontologiczny punkt widzenia jest podporządkowany perspektywie teleologicznej, wówczas przedział między tym, co powinno być, a tym, co jest, wyda się łatwiejszy do pokonania niż w przypadku bezpośredniego porównania między opisywaniem a nakazywaniem przepisów bądź, wedle zbliżonej terminologii: między sądami o wartości a sądami o faktach (s. 284).

Ricoeur „wykaże" to poprzez podwójną argumentację o przeciwstawnych wektorach: najpierw wyszuka uniwersalne aspekty praktyk, potem zaś położy nacisk na jednostkowo-dialogiczne podłoże uniwersalności, starając się dowieść, że regulatywna, formalistyczna i w pewnym stopniu apodyktyczna idea "państwa celów” Kanta bazuje na faktyczności ludzkiego życiowego doświadczenia (przykładem, a jednocześnie postulatem będzie tu idea sprawiedliwości dystrybucyjnej, rozdzielczej, która, zdaniem Ricoeura, opiera się na "doświadczeniu etycznym”). Jak pisze Wolicka: „Naginając procedury analizy do reguł własnej, hermeneutycznej «dialektyki koniunk-

${ }_{29}$ Zob. R. Linton, Kulturowe podstawy osobowości, tłum. A. Jasińska-Kania, wstęp J. Szacki, Warszawa 1975. 
cyjnej», Ricoeur usiłuje zakorzenić deontologicznie zdefiniowane, legalistyczne zasady sprawiedliwości (principles de justice) w etycznym doświadczeniu - poczuciu sprawiedliwości (sens de la justice) - w którym wyraża się celowość działania w imię wspólnego dobra" ${ }^{30}$. Krótko mówiąc: obronić należy tezę o pierwotności etyki względem moralności (w rozumieniu, jakie Ricoeur nadaje tym terminom) i o podporządkowaniu szacunku dla siebie poważaniu siebie. Tak zarysowany zostanie jednak dopiero punkt wyjścia, "punkt Archimedesowy", na którym oparta będzie pełna artykulacja struktury namysłu jako podstawy dążenia etycznego.

Tym, co uniwersalne w sytuacyjnej praxis, są: zasada "średniej miary”, zdolności (możność działania, wybór kierujący się racjami, ocena celów działania), "każdorazowość «mojości»”31, egzystencjały (przede wszystkim troska), dobra wola oraz możliwość otwarcia pola uniwersalizacji poprzez maksymę. Uniwersalna jest też biblijna Złota Reguła: „Wszystko więc, co byście chcieli, żeby ludzie wam czynili, i wy im czyńcie” (Mt 7,12), którą Ricoeur próbuje "pogodzić” $\mathrm{z}$ transcendentalną uniwersalizacją imperatywu u Kanta, a - w innym już miejscu - rozszerzyć o Jezusowe przykazanie, by kochać nieprzyjaciól, wyrażone w Kazaniu na Górze 32.

Jak widać, dwa pierwsze uniwersalne aspekty praktyk (zasada „średniej miary" i zdolności) zaczerpnięte są od Arystotelesa, dwa kolejne - dialogiczna "mojość” i egzystencjały - od Heideggera, następne dwa - dobra wola i maksyma - od Kanta, ostatnie zaś, wraz z jego rozwinięciem, z Biblii. Uniwersalne są również kooperacja (MacIntyre) i refleksyjna dialogiczność (Ricoeur). Ten potężny, komplementarny i częściowo zazębiający się konglomerat filozoficzno-religijny pozwala pokonać dystans między „wzorcami doskonałości" a "dobrym życiem".

Odwrotną, czy raczej zwrotna drogę przeciera z kolei ugruntowanie i oparcie sprawiedliwego działania struktur i instytucji społecznych na jednostkowym doświadczeniu etycznym. Najpierw należy jednak oddzielić sprawiedliwość egalitarystyczną, arytmetyczną („każdemu po równo”), od sprawiedliwości dystrybucyjnej, proporcjonalnej („każdemu podług za-

30 E. Wolicka, Narracja i egzystencja, op. cit., s 161.

31 „Sobość - stwierdza Heidegger - jest każdorazowo moja” (M. Heidegger, Bycie i czas, tłum. B. Baran, Warszawa 1994, §25). Ricoeur zaś zapytuje, i odpowiada: „Otóż na czym opiera się to «każdorazowo», jeśli nie na niewypowiedzianym odniesieniu do innego?" (s. 300).

32 „Miłość wywiera na sprawiedliwości presję, by ta rozszerzała ów krąg wzajemnego uznania. I bardzo często dzieje się tak, że właśnie poprzez przekroczenie ustalonego porząd$\mathrm{ku}$, poprzez gwałtowne działanie wyjątkowych przykładów, miłość kontynuuje swe dzieło nawracania na poziomie samego sensu sprawiedliwości"; P. Ricoeur, Miłosne posłuszeństwo, op. cit., s. 182. 
sług"), dla której fundament - i tu następuje owo zwrotne związanie - odnajdzie Ricoeur nie gdzie indziej, jak w strukturze Arystotelesowskiej przyjaźni (przyjaciele tyleż sobie dają, ile nawzajem od siebie otrzymują). Potwierdzi ją też zasada absolutnej symetrii ,ja” $\mathrm{i}$,Ty" z filozofii dialogu.

Elżbieta Wolicka, pozostając czujna i częstokroć krytyczna wobec tego rysu filozofowania Ricoeura, który nazywa „dialektyką koniunkcyjną”, zauważa, że konsekwencją takiego przekonania powinno być rozszerzenie przyjacielskiej dialogiczności na sferę publicznej debaty (sam Ricoeur zresztą to czyni, polemizując $\mathrm{z}$ jednej strony $\mathrm{z}$ Johnem Rawlsem, $\mathrm{z}$ drugiej z Karlem-Otto Aplem i Jürgenem Habermasem; dyskusje te wykraczają jednak poza przyjętą tu perspektywę omówienia). Jak jednak, osiągnąwszy ów „punkt Archimedesowy”, powrócić do indywidualnego doświadczenia / sprawdzianu etycznego i wyposażyć jednostkę w "sytuacyjną mądrość praktyczną" obecną pod postacią "przekonania”, czyli - by użyć określeń Arystotelesa - takiego phronesis, które wynika z samej aisthesis: roztropności zawartej w samym postrzeżeniu sytuacji, idealnego oglądu sytuacyjnego. Innymi słowy - czy dobro może pojawić się w sytuacyjnej percepcji etycznej, tak jak piękno pojawia się, momentalnie, w percepcji estetycznej?

Przytoczmy długi fragment z $O$ sobie samym jako innym, w którym Ricoeur przedstawia trzy sposoby rozwiązania tego problemu poprzez "wprowadzenie hermeneutycznego punktu widzenia":

To w nieustannym wysiłku interpretacji działania i siebie samego trwa poszukiwanie zgodności między tym, co nam się wydaje najlepsze dla całokształtu naszego życia, a preferencyjnymi wyborami (postanowieniami), które rządzą naszymi praktykami. Istnieje kilka sposobów, by wprowadzić na tym końcowym etapie hermeneutyczny punkt widzenia. Przede wszystkim między naszym dążeniem do „życia dobrego" a naszymi konkretnymi wyborami rysuje się rodzaj hermeneutycznego koła wskutek wahadłowej gry między pojęciem „życia dobrego" a najbardziej znaczącymi postanowieniami naszej egzystencji (kariera, miłość, zajęcia czasu wolnego etc.). Rzecz się ma jak z tekstem, w którym całość i część są rozumiane poprzez siebie wzajemnie. Następnie pojęcie interpretacji dodaje do zwykłego pojęcia znaczenia pojęcie znaczenie dla kogoś. Interpretować tekst działania to w przypadku sprawcy interpretować samego siebie. [...] Z etycznego punktu widzenia interpretacja siebie staje się poważaniem siebie. Z kolei poważanie siebie podziela los interpretacji. Jak ta ostatnia, daje sposobność do sporu, podawania w wątpliwość, współzawodnictwa, słowem: do konfliktu interpretacji $\mathrm{w}$ akcie sądu praktycznego. Oznacza to, że poszukiwanie zgodności między naszymi życiowymi ideałami a naszymi postanowieniami, które same mają żywotne znaczenie, nie podlega tego rodzaju weryfikacji, jakiej można oczekiwać od nauk opartych na interpretacji. Trafność interpretacji zależy od aktu sądu, który w najlepszym wyrazie może górować [nad innymi sądami - przyp. P.J.], przynajmniej w oczach innych, pod względem prawdopodobieństwa (s. 297-298). 
Struktura poświadczenia ostatecznie przyjmuje więc analogiczną jak u MacIntyre'a sankcję w praktykach i instytucjach społecznych (tym samym zbliżając się do Heglowskiego „uznania”) oraz probabilistyczną wyłącznie, nie zaś absolutną weryfikację. "Jaki rodzaj gwarancji może zapewnić wspólnota?” - pytał Umberto Eco, i odpowiedział: „Sądzę, że zapewnia gwarancję co do faktów. Nasz gatunek zdołał przetrwać dzięki przypuszczeniom, które okazały się statystycznie owocne" 33 . Czy jednak zapewnia analogiczną gwarancję odnośnie do interpretacji? Sam fakt konieczności ostatecznego potwierdzenia tego, co w toku odniesienia decyzji do planu życia i dialogicznej samointerpretacji okazało się prawdziwym obrazem działania i działającego, a także konieczność wystawienia się na "konflikt interpretacji”, świadczą o tym, że probabilistyczna wartość potwierdzenia słabsza jest niż wiedza płynąca ze statystycznie skutecznych przypuszczeń. Jednostkowa odpowiedzialność i niepokój wynikający z osamotnienia - obecny aż do chwili sankcji poświadczenia, a eskalowany w czasie oczekiwania na nie - pozostają, choć znacząco osłabione wymienionym wcześniej filozoficzno-religijnym „wsparciem”, obecne na co najmniej trzech poziomach: wyboru i interpretacji „życia dobrego", interpretacji relacji między konkretną decyzją a wizją "dobrego życia” oraz wyboru innych jako godnych atestacji trafności samointerpretacji.

Mimo więc najsolidniejszych możliwych fundamentów "sytuacyjnej mądrości praktycznej" (wymieńmy, na zasadzie imion własnych, ich składowe: Arystoteles, Jezus, Kant, Heidegger, MacIntyre, Ricoeur), pozwalających jednostce na momentalne i niezapośredniczone związanie aisthesis z phronesis, ostateczną instancją sankcjonującą pozostają inni:

Trafność interpretacji zależy od aktu sądu, który w najlepszym razie może górować, przynajmniej w oczach innych, pod względem prawdopodobieństwa, nawet jeżeli w oczach sprawcy jego własne przekonanie graniczy z tego rodzaju przeżytą oczywistością, która przy końcu księgi VI Etyki Nikomachejskiej skłania [Arystotelesa] do porównania phronesis z aisthesis (s. 298; podkr. P.J.).

Te drobne, wyłuszczone sygnały - „w najlepszym razie” i „nawet jeżeli” - najlepiej oddają ostatecznie nieusuwalne osamotnienie i niepokój tożsamości etycznej opartej na narracji. Jak pisze Grażyna Lubowicka w tekście o znamiennym tytule Cogito zranione. Moralność pęknięta:

Poświadczenie wskazuje na wiedzę, jaka w tym refleksywnym zwrocie [odpowiedzi sumienia na wezwanie Innego - przyp. P.J.] może być uzyskana. Ta wiedza o sobie, to ujęcie się w swej tożsamości jest teraz świadomością siebie - moralną; jest zrozu-

33 U. Eco, Replika, [w:] U. Eco, R. Rorty, J. Culler, Ch. Brooke-Rose, Interpretacja i nadinterpretacja, red. S. Collini, tłum. T. Bieroń, Kraków 2008, s. 162. 
mieniem nas samych nie jako podmiotu poznania przedmiotowego, lecz jako podmiotu odpowiedzialności moralnej. To powtórzenie idei refleksji, którego dokonuje Ricoeur, ma jednak pewną cechę: konieczność pogodzenia się z niepewnością, omylnością, nieprzejrzystością wiedzy o nas samych, z dysproporcją, nieadekwatnością tej szczególnej relacji siebie do siebie [podkr. P.J.] ${ }^{34}$.

Tym samym ten wieńczący punkt - poświadczenia przez innych poświadczonego przez drugiego poświadczenia samego siebie - jest jednocześnie konieczny oraz, jak wskazałem, niedostateczny i nieostateczny; „kruchy", jak to określa Lubowicka. A mimo to - jak się zdaje - najmocniejszy z możliwych.

\section{To find phronesis in aisthesis. Paul Ricoeur on solitude of acting and choice}

\section{Summary}

This article tries to answer the question whether is possible to achieve such a wisdom of situational overview to recognize right way of acting in a situation of tragic moral choice, connected with incertitude and loneliness of decision-making subject. Paul Ricoeur's Oneself as Another is discussed here as well as its main reference points, that is Aristotle's Nicomachean Ethics and Kant's moral doctrine. The solution given by Ricoeur as it is claimed - is the strongest one, even if insufficient to ultimately eliminate anxiety and incertitude that moral subject is fated to.

34 G. Lubowicka, Cogito zranione. Moralność pęknięta, [w:] Horyzonty interpretacji, op. cit., s. 142-143. Wcześniej zaś autorka stwierdza, że: „Wiedza utożsamiona przez Ricoeura z poświadczeniem jest jednak naznaczona słabością, omylnością, nieprzejrzystością, wątpliwościami, ma wymiar prawdziwości, który należy już nie do sfery pewności, ale do sfery doxa, do sfery wiary, zaufania i wiarygodności"; ibidem, s. 143. 